\title{
Refinancing Operations: Evolution of the Role and Identification of the Influence on the Ukrainian Banking System's Liquidity
}

\author{
Pavlo Ilchuk \\ Department of Management Technologies \\ Lviv Polytechnic National University \\ Lviv, Ukraine \\ pavlo.g.ilchuk@1pnu.ua
}

\author{
Olha Kots \\ Department of Finance \\ Lviv Polytechnic National University \\ Lviv, Ukraine \\ olha.o.kots@lpnu.ua
}

\begin{abstract}
The main goal of the research is to determine the importance of the refinancing mechanism in the system of Ukrainian banking system's liquidity regulation. The separate tasks by which the goal of the research is achieved are: research the legal regulation of NBU's usage the refinancing instruments and detection the deficiencies; research the refinancing mechanism impact on the liquidity of Ukrainian banking system; define the type and level of correlation between the refinancing operations and the banking system liquidity. Execution of such tasks also allows obtaining tools for forecasting the Ukrainian banking system's liquidity level, which depends on the intensity of the refinancing instruments usage.
\end{abstract}

Keywords-banking system, monetary policy, refinancing, central bank, liquidity

\section{INTRODUCTION}

The practice of using by the central bank the refinance other banks serves as a research object for a long period of time. The specialty of such researches is their versatile orientation and application of results both in the activities of the central bank (since most of such researches aim to improve the monetary policy of the central bank and measures to ensure financial stability), as well as in the activities of other banks, as well as in developing measures to improve a mechanism for regulating financial markets.

\section{REVIEW OF RECENT RESEARCHES}

Most authors investigate the mechanism of refinancing within the framework of the monetary policy implementation by the central bank. In particular, V. Stelmakh and N. Shulga consider the mechanism of refinancing within the framework of the NBU's performance of the lender of last resort and during the functioning of the monetary policy's transfer mechanism on the economy $[41$, p. $78-88 ; 42$, p. 80 , p. 133 143]. O. Dzubluk, Yu. Galitsayskaya and R. Mikhaylyuk consider the specialties of using the NBU a refinancing tool within the framework of ensuring financial stability of banks, as well as an instrument for regulating the aggregate money supply in the economy [7, p. 129; 8, p. 148-150]. Similarly, $\mathrm{V}$. Kovalenko investigates the specialties of the NBU's using of the refinancing mechanism during 2000-2008 [15, p. 9195], however, combining a refinancing with a discount rate instrument within the unified interest rate policy of the NBU and within the scope of the NBU's functions as the lender of last resort [15, p. 107-110]. Investigating the mechanism of refinancing within the framework of the implementation of the central bank's monetary policy, S. Yegoricheva and V. Kovalenko also consider refinancing as an element of the system of financial security of the Ukrainian banking system [9, p. 249-259; 14, p. 107, p. 182]

A. Volzhov investigates the obligatory conditions for the implementation of the mechanism of refinancing of banks, emphasizing that the effectiveness of using such an instrument of regulation of monetary demand and supply within monetary policy largely depends on the level of central bank control of the target direction of financial resources [47, p. 248-249].

However, it is interesting to distinguish between the directions of functioning of the refinancing mechanism and the concentration of research on particular features of such a mechanism. So O. Moskvichova carried out the analysis of the refinancing mechanism as a form of state regulation of the credit services market and the instrument of regulation of the credit market [27, p. 310-314]. M. Kuzmak, as well as O. Metlushko, investigate the problems of reducing the stability of the banking system and determine the conditions and parameters of the refinancing instruments to increase the stability of the banking system in particular and the financial and credit sector, in general [16, p. 287-294; 24, p. 131-135]. O. Melnichenko investigates the role of refinancing in the NBU emission activities and emphasizes the existence of a significant failing in the NBU emission activities - the low level of using the refinancing mechanism for the issue of money, while the excessive use of the currency channel for the issue of money, which threatens to increase the level of dependence of the Ukrainian economy on the economy countries whose currencies the NBU most often uses during such operations [22, p. 288-295]. A. Maksimova investigated the problems of the analysis and control of refinancing operations of banks and developed a number of measures to improve them, made proposals for improving the accounting system of refinancing operations for the NBU and other banks [18, p. 48-59]. Informative are researches of $\mathrm{G}$. Bashnyanin, Y. Tchaikovsky and M. Chekhovskaya concerning the features and problems of bank refinancing in the post-crisis period, in particular, through the creation of threats to the economic security of Ukraine [1, p. 173-177; 5, p. $67-70 ; 43$, p. 107-111]. A significant number of scientists $[19,25,48]$ investigate the possibilities of variation regulation of banks' liquidity using the refinancing mechanism. An important area of researching the refinancing mechanism is the development of methods for analyzing 
refinancing operations, a significant contribution to this direction of scientific research carried out O. Melnichenko [23, p. 272-279]. Important are researches of different types of refinancing, in particular the least common type - longterm refinancing, the implementation of which is always due to the need to overcome significant violations of financial stability of individual banks or the entire banking system, in particular, the research of G. Bortnikov [4, p. 73-78]. The modern economy is as globally as possible, which is especially reflected in the activity of financial markets, and therefore the research of $\mathrm{O}$. Melnichenko concerning refinancing of banks in the conditions of globalization is relevant $[20$, p. $51-53 ; 21]$. Also relevant is the research of M. Boldin on the analysis of foreign experience of the effective application of the mechanism of refinancing in support of banking systems [2, p. 84-94] and on the legal regulation of the refinancing mechanism [3, p. 166-169].

Also, scientists identify the problem of using the central bank's refinancing mechanism for deposit corporations. One of the problems that the researchers point out is the misuse of the received resources, and in particular the direction of the received resources from the central bank to perform speculative operations in the currency market, instead of implementing measures to support liquidity or increase the loan portfolio. O. Dzyublyuk and Yu. Galitsayskaya, based on analytical calculations, draw conclusions about the inappropriate use by individual banks of resources received from the NBU in 2008, which negatively affected the hryvnia exchange rate and increased the level of control of the NBU by using banks' funds received within the framework of refinancing [7, p. 132-133]. The authors [13] have shown a similar problem in using the refinancing mechanism and proved the existence of a straight linear link between the volumes of assets in foreign currency and the financial results of Ukrainian banks over a longer period 2010-2015. Such results prove the receipt of speculative profit by domestic banks due to attraction of refinancing NBU [13, p. 821]. However, there haven't been many critical views on the implementation of the NBU refinancing policy over the past few years. For such reasons, the important research in the field of regulating the NBU's liquidity of the banking system as a whole, and with the use of refinancing instruments can be considered [37]. V. Rudan insists on the mistakes of changing the approaches to determining the level of banking system's liquidity and the negative impact of the use of deposit certificates in order to absorb excess liquidity, which causes significant losses of the investment potential of the banking system [37, p. 175]. Despite the depth of research by scholars on refinancing issues, the relationship between the refinancing mechanism and the level of liquidity of the banking system remains under-researched, and no models for such a relationship have been identified.

\section{EVOLUTION OF USAGE IN UKRAINE}

Regulatory regulation of the refinancing of banks in Ukraine has long practice and was carried out on the basis of a wide range of normative acts. In particular, since 2002 (NBU Board Resolution No. 238 dated 02.08.2003), the NBU has been used a refinancing instrument to stimulate long-term lending [30]. The purpose of using the NBU refinancing instrument was the development of investment activity in Ukraine, as banks could obtain financial resources at the NBU exclusively for lending to effective innovative and investment projects of economic entities.

Already in 2003 (12.02.2003), the NBU practically does not change the previous purpose of the refinancing, but substantially expands it, it plans to use the refinancing mechanism for the development of the domestic market of products, the production of competitive and import-substitute products, and products that will strengthen the export potential of the economy of Ukraine [28]. However, in the same year, the NBU abolished the previous resolution, approving the Provisional regulations on the procedure for long-term refinancing (maintenance of liquidity) of banks.

Such a concept of using the NBU to refinancing mechanism was applied to 2010, confirmation of which was the introduction of the NBU Regulation "On refinancing and providing NBU loans to Ukrainian banks in order to stimulate lending to the Ukrainian economy for the period of its release to pre-crisis parameters" [31]. Further, the NBU applied a refinancing mechanism to stimulate the development of priority entities or sectors of the economy only within the framework of cooperation with international financial and credit institutions.

The change in the concept of applying the NBU to the refinancing mechanism began in the end of 2003 when the NBU in its Resolution No. 584 of 24.12.2003 [29] provided for the use of the refinancing instrument, primarily for the effective regulation of bank liquidity and the performance of the function of the lender of last resort. The previous concept of the NBU's refinancing mechanism was based on the approach of the active participation of the central bank in the development of the economy through the indirect funding of priority entities or sectors of the economy. Because NBU specialists participated in the evaluation of the effectiveness of those innovation and investment projects that were financed at the expense of the funds provided by the NBU to banks, and therefore decided on the appropriateness of financing the development of individual entities or sectors of the economy. The next concept of using the NBU refinancing mechanism is, in particular, more logical and simple, since it only involves regulating the stability of the financial sector of the economy, including through mechanisms for regulating the banking sector through the use of refinancing instruments. Further, the NBU uses the refinancing mechanism by providing stabilization loans (in the form of a permanent refinancing line for overnight loans and refinancing loans (through a quantitative or interest rate tender) for up to 14 days and up to 90 days), which is accordingly regulated by a number of other Resolutions of the NBU, in particular [32]. Thus, the NBU's refinancing mechanism is used to regulate the liquidity of the deposit corporations sector, using mainly short-term instruments (in some cases, the NBU's refinancing instruments may be extended by up to 5 years) [33]. Subsequently, such a concept of using the refinancing mechanism has been improved and expanded, which is also confirmed by the Law of Ukraine "On the NBU" [45], which specifies the target direction of the refinancing mechanism - influence on monetary turnover and lending [45, article 1].

An intermediate stage in the practice of using the refinancing mechanism can be considered as two periods of significant financial crises in the Ukrainian economy. During 
such periods, the NBU did not use the refinancing mechanism to stimulate the development of individual entities through refinancing instruments, nor did it implement classical measures to regulate liquidity of the banking sector through refinancing instruments. Instead, at the end of 2008 and early 2009, the NBU implemented a complex set of measures to stop the outflow of funds from the banking system, stabilize its acceptable level of liquidity and ensure that banks can fulfill their obligations. So in 2009, the NBU and the Cabinet of Ministers of Ukraine jointly approve the Resolution No. 44 of 29.01.2009 "On the procedure for refinancing banks in the period of the financial and economic crisis" [36], which operated until March 2009 and on the basis of which the NBU provided refinancing banks. During this period, the procedure for granting refinancing loans, the refinancing period and the range of goals whose achievement was foreseen within the framework of the refinancing mechanism, as well as sources of refinancing of banks (one of such sources was the State Budget (according to [44]) was changed. Between 01-032009 , the NBU, jointly with the authorized representative of the Cabinet of Ministers, made a decision on refinancing the banks, the purposes of applying the refinancing mechanism covered the overcoming of problems from the stabilization of the national currency exchange rate and ensuring the implementation of settlements between the entities, ending, of course, maintaining the liquidity of banks at the required level [36, p. 3].

\section{ESSENCE OF REFINANCING OPERATIONS}

Regarding the content of refinancing, most scientists adhere to the legislative definition: refinancing operations of banks - operations to provide loans to banks in the order established by the NBU [33, p. 1]. However, some scientists studying the concept of refinancing, differently determine its essence (Table 1).

TABLE I. INTERPRETATION OF THE CONCEPT OF REFINANCING IN THE ECONOMIC LITERATURE

\begin{tabular}{|c|c|}
\hline Authors & Definition \\
\hline $\begin{array}{l}\text { E. Shepel } \\
{[39, \text { p. } 773]}\end{array}$ & $\begin{array}{l}\text { a complex system of monetary policy realization, } \\
\text { the functioning of which goals to support the } \\
\text { liquidity of banks and regulation of money supply }\end{array}$ \\
\hline $\begin{array}{l}\text { L. Vdovenko } \\
{[46, \text { p. } 10]}\end{array}$ & $\begin{array}{l}\text { a mechanism for implementing monetary policy } \\
\text { aimed at lending to banks and balancing money } \\
\text { supply and demand }\end{array}$ \\
\hline $\begin{array}{l}\text { O. Melnichenko } \\
\text { [21] }\end{array}$ & $\begin{array}{l}\text { process of changes transfer from participants in the } \\
\text { global market and national agents to banks with } \\
\text { subsequent influence on the socio-economic } \\
\text { development of the national economy }\end{array}$ \\
\hline $\begin{array}{l}\text { V. Shevchuk } \\
{[40, \text { p. } 12]}\end{array}$ & $\begin{array}{l}\text { short-term compensation previously issued money } \\
\text { in the form of loans (broad) and provision of } \\
\text { financial resources to second-tier banks through } \\
\text { credit and financial instruments, accompanied by } \\
\text { the replacement of one debt obligation to another in } \\
\text { order to achieve the stated objectives as on the } \\
\text { micro, and on the macro level (narrow) }\end{array}$ \\
\hline $\begin{array}{l}\text { A.Chubenko et } \\
\text { al. }[6, \text { p. } 587]\end{array}$ & operations to provide loans to banks \\
\hline $\begin{array}{l}\text { G. Saltykov } \\
{[38, \text { p. } 142]}\end{array}$ & $\begin{array}{l}\text { the process of obtaining a new loan by a credit } \\
\text { institution in exchange for debt instruments } \\
\text { available to it or on condition that they are pledged }\end{array}$ \\
\hline $\begin{array}{l}\text { Yu. Garkusha, } \\
\text { I. Bakhchivan- } \\
\text { zhy }[10, \text { p. } 250]\end{array}$ & $\begin{array}{l}\text { providing central bank of commercial banks with } \\
\text { additional reserves on a loan basis, namely } \\
\text { borrowed reserves }\end{array}$ \\
\hline
\end{tabular}

Source: formed by authors according to the $[6,10,21,38,39,40,46]$
The mechanism for refinancing banks should be defined as an instrument of the monetary policy of the central bank, which is confirmed in Ukraine at the legislative level - this is stated in the Law of Ukraine "On the National Bank of Ukraine" [45].

Currently, the procedure for the NBU to use the refinancing mechanism is regulated by parts II (chapters 3-5) and VI (chapter 13) of the Resolution No. 615 dated 17.09.2015 [33]. Thus, at the present moment, the NBU carries out operations to refinance banks in the form of refinancing loans (a loan provided by the bank through a quantitative or interest tender on maintaining liquidity) [33, part 1]. However, it should be noted that, despite the regulatory delineation of the refinancing mechanism (in the form of refinancing operations) and other liquidity management instruments (in the form of repo transaction, operations with own debt and with government bonds of Ukraine) [33, part. 2, chapter 4], In contrast to this provision, the NBU actually counts repurchase repo transaction to the refinancing mechanism, which is confirmed by [12]. Thus, there are some conflicts in the legal regulation and the essential identification of the refinancing mechanism.

In addition, the NBU applies the classification of refinancing instruments according to the criterion of the cost of refinancing loans [12, p. 7]. The Resolution of the National Bank of Ukraine No. 615 explicitly regulates types of collateral for refinancing operations.

The NBU carries out refinancing operations using the refinancing rate - expressed as a percentage of payments for loans granted to banks, which is established by the NBU in order to influence monetary turnover and lending. Thus, as of March 21, 2019, the interest rate on long-term refinancing loans is set at a level not lower than the NBU key policy rate plus two percentage points and may change during the term of use of the loan, subject to changes in the NBU key policy rate [33, part 2, chapter 3].

\section{ANALYSIS OF REFINANCING OPERATIONS STATISTICAL DATA}

An important issue of the effective use of the refinancing mechanism by the central bank is using of such a mechanism in the regulation of monetary turnover, namely in the regulation of the money supply. According to some data [25, p. 75], the share of the currency channel in the formation of the money supply is $80 \%$, while the priority should be a credit channel with the use of a refinancing mechanism.

The refinancing mechanism is the main instrument for regulating the banking system's liquidity. According to the NBU's previous approach (which was formed prior to 2008), the definition of the level of banking system's liquidity is based on the amount of funds on correspondent accounts of banks. The NBU noted that the banking system's liquidity was formed on the basis of obligatory reserve requirements, which are on correspondent accounts of banks with the NBU and free liquidity (other funds on correspondent accounts) [26, p. 99; 34].

Given that required reserves of banks are placed on correspondent accounts with the NBU, the NBU determined the rate of free (insufficient) liquidity $\mathrm{F}(\mathrm{I})_{\mathrm{L}}$ as the difference between the amount of funds on correspondent accounts of banks and the size of required reserves [26, p. 99-100]: 


$$
F(I)_{L}=C A-M R
$$

where CA - the amount of funds on correspondent accounts, UAH; MR - the amount of required reserves with the NBU, UAH.

Subsequently (according to [37, p. 172], from the middle of 2014), the NBU has changed the methodology for calculating the banking system's liquidity and calculates this indicator, based on another approach, such as the amount of funds on correspondent accounts with the NBU and the amount of debts on deposit certificates of the NBU, which is confirmed by data [17, p. 17] and the annex to [11].

Also, the NBU defines a large range of factors that affect the banking system's liquidity, except for refinancing. These factors include: government operations, changes in cash, foreign exchange interventions, other operations and monetary operations of the NBU [11, annex]. Dynamics of Ukrainian banking system's liquidity (the indicator is calculated by the second approach of the NBU) is shown in Fig. 1.

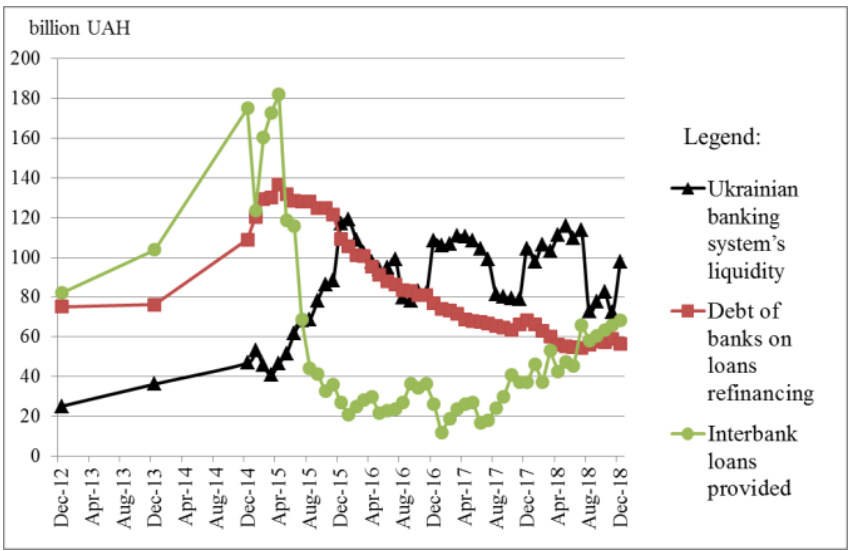

Fig. 1. Dynamics of the banking system's liquidity and instruments for its change in 2012-2018

Source: calculated by authors according to [34]

According to Fig. 1 it can be argued that Ukrainian banking system's liquidity in 2012-2018 has significantly increased, with a steady positive dynamics. An important instrument for ensuring and regulating the banking system's liquidity during the crisis period of 2013-2015 was the refinancing mechanism, as evidenced by the peak of debt refinancing loans for 2014-2015. It was during this period that the level of liquidity was rather low (UAH 46.8 billion in December 2014), which led to the need for the NBU to use the refinancing mechanism to increase the liquidity of the banking system. Independently, banks actively pursued measures to find additional liquidity and used the opportunities of interbank lending. Thus, in 2012-2015, the interbank lending market was the main provider of liquidity for individual banks, since the volume of interbank loans provided in December 2014 - the first half of 2015 reached UAH 182 billion, an absolute record in the history of the Ukrainian banking system for factors supporting the liquidity of individual banks. It was at the end of 2015 that the NBU began actively using deposit certificates to regulate banks' liquidity (the increase in debts under deposit certificates during the year 2015 amounted to $366.57 \%$ ), which instantly (for 4 months) - during April-August 2015 reduced the volumes provided interbank loans more than 4 times (from UAH 182.10 billion to UAH 44.20 billion).

Thus, in 2015, the NBU substantially improved the mechanism for regulating the banking system's liquidity, leveling out the impact of interbank lending, instead giving rise to a priority of the refinancing mechanism and deposit certificates (the central (and often the only) regulator of such mechanisms is the NBU), which maximized the influence of the NBU on regulation of the banking system's liquidity.

Subsequently, the refinancing mechanism began to be used at significantly lower volumes (in comparison with other instruments and liquidity factors of the banking system), while the debt repayment refinancing loans granted in 2014-2015 in significant volumes decreased by more than 2.5 times before completion 2018. During 2016-2018, refinancing loans were used to a greater extent as an adjustment tool for providing liquidity to the banking system and as a channel for withdrawing money supply from turnover. Confirmation of this conclusion is the dynamics of volumes (net turnover calculated as the difference between the amount of funds that are directed to the turnover and the amount of money withdrawn from the turnover by the appropriate instrument / factor for a particular period) of refinancing and volumes of transactions with other instruments. So according to Fig. 2 in 2016-2018, there is a steady, fluent flow of refinancing operations, indicating the use of refinancing exclusively as a tool for maintaining and regulating the liquidity of individual banks, the main and clear goal of which is to only stabilize the level of liquidity of individual banks, while achievement of the NBU's goals is not expedient to regulate money supply in turnover through a refinancing instrument.

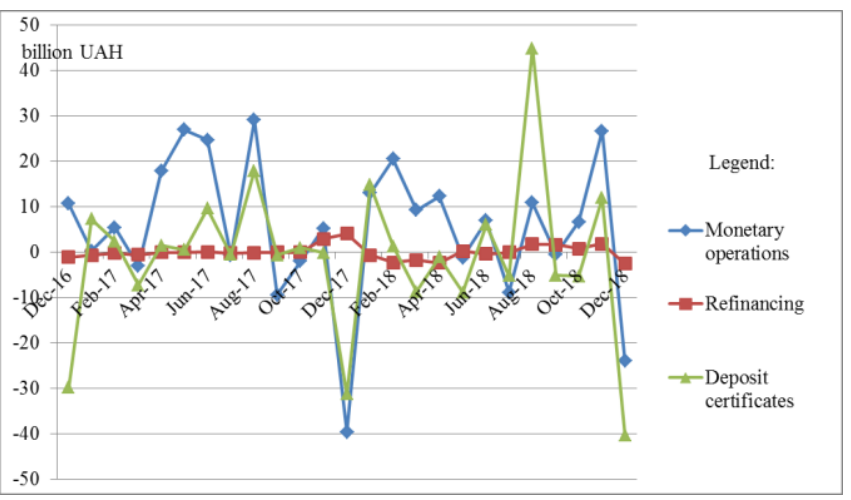

Fig. 2. Dynamics of net refinancing volumes, operations with deposit certificates and other monetary operations in 2016-2018

Source: calculated by authors according to [34]

Instead, the use of NBU deposit certificates, as opposed to the refinancing instrument, is primarily aimed at instantaneous increase in liquidity or absorption of excess banking system's liquidity (which is displayed both in volumes of operations and volatility). A similar goal is achieved by the NBU and other monetary operations (Fig. 2).

Indeed, a similar volatility and significant volumes of other monetary operations indicate, first of all, the implementation of NBU measures to achieve the goal of regulating the money supply in turnover. Thus, it can be argued that the NBU significantly narrowed the scope of application of the refinancing instrument in 2016-2018 and significantly differentiated the goals of various monetary 
policy instruments. The refinancing application in 2016-2018 narrowed down to the point of support of the liquidity of individual banks and to ensure a stable level of the banking system's liquidity, that is, maintaining the refinancing status as the most stable and predictable instrument used in its current activities exclusively to maintain liquidity.

\section{LiNK BETWEEN THE REFINANCING MECHANISM AND THE LEVEL OF THE BANKING SYSTEM'S LIQUIDITY INDICATOR}

In this paper, the problem of identifying and characterizing the features of the link between the refinancing mechanism and the level of the banking system's liquidity indicator was carried out on the basis of statistical data for the period 2016-2018 [35]. In addition to the refinancing mechanism, the NBU defines monetary operations, transactions with deposit certificates and autonomous factors as a system of influence on Ukrainian banking system's liquidity. Therefore, based on the application of the correlation method between the abovementioned factors and the indicator of banking system's liquidity, results were obtained confirming the closest link between the dynamics of the banking system's liquidity indicator and the amount of refinancing (Table 2).

TABLE II. RESULTS OF THE CORRELATION BETWEEN THE UKRAINIAN BANKING SYSTEM'S LIQUIDITY AND THE MAIN FACTORS OF INFLUENCE DURING 2016-2018

\begin{tabular}{|l|c|}
\hline \multicolumn{1}{|c|}{ Indicators } & $\begin{array}{c}\text { The level of interconnection } \\
\text { (1- a straight line, } \mathbf{- 1}-\mathbf{a} \text { close inverse, } \mathbf{~ - ~} \\
\text { absent })\end{array}$ \\
\hline Monetary operations & -0.0966 \\
\hline Refinancing & -0.4626 \\
\hline Deposit certificates & -0.3855 \\
\hline Autonomous factors & 0.3514 \\
\hline
\end{tabular}

The link between the dynamics of the banking system's liquidity indicator and the volume of refinancing is close inverse, which, first of all, indicates the withdrawal of money supply through the credit channel. However, the regulation of Ukrainian banking system's liquidity is most sensitive to changes in the volume of refinancing, therefore such instrument should be defined as the most effective and most risky from the point of view of importance of influence on the general level of liquidity.

Consequently, the significance of the impact of the refinancing mechanism on the liquidity of the Ukrainian banking system's liquidity is confirmed, and the level of interconnection with the refinancing factor is the highest. That is why the NBU needs to further improve the mechanism for controlling refinancing operations and to take into account that any changes in the volume of refinancing are most reflected in changes in the Ukrainian banking system's liquidity.

Using the regression method, different functions of the banking system's liquidity interconnection (dependent variable) and refinancing volumes (independent variable) were constructed based on the data from the increased sample for 2012-2018 (Table 3). The highest level of reliability of a function that describes the interconnections between the banking system's liquidity and the amount of refinancing is observed during the modeling of the cubic interconnection $\left(\mathrm{R}^{2}=0.3383\right)$, and therefore the most accurately describes the interconnection between the banking system's liquidity and the amount of refinancing of the Ssimilar curve.

TABLE III. RESULTS OF REGRESSION ANALYSIS OF THE BANKING SYSTEM'S LIQUIDITY (Y) AND REFINANCING (X) INTERCONNECTIONS WITH THE SAMPLE FOR 2012-2018

\begin{tabular}{|c|c|c|c|}
\hline Indicators & $\begin{array}{l}\text { Linear inter- } \\
\text { connection }\end{array}$ & $\begin{array}{l}\text { Quadratic inter- } \\
\text { connection }\end{array}$ & $\begin{array}{l}\text { Cubic inter- } \\
\text { connection }\end{array}$ \\
\hline Multiple R & 0.4676 & 0.5105 & 0.5816 \\
\hline $\mathrm{R}^{2}$ & 0.2187 & 0.2606 & 0.3383 \\
\hline Normaly $\mathrm{R}^{2}$ & 0.2027 & 0.2298 & 0.2961 \\
\hline $\begin{array}{c}\text { Standard } \\
\text { error }\end{array}$ & 21.2433 & 20.8793 & 19.9610 \\
\hline $\begin{array}{c}\text { Number of } \\
\text { observations }\end{array}$ & 51 & 51 & 51 \\
\hline $\begin{array}{l}\text { F-criterion } \\
\text { Fisher's }\end{array}$ & 13.7131 & 8.4596 & 8.0097 \\
\hline $\begin{array}{l}\text { Regression is } \\
\text { significant } \\
\left(\mathrm{F}_{\text {actual }}>\mathrm{F}_{\mathrm{tab}}\right)\end{array}$ & significant & significant & significant \\
\hline $\begin{array}{l}\text { Interaction } \\
\text { function }\end{array}$ & $\begin{array}{c}y=121.9691- \\
0.4194 x\end{array}$ & $\begin{array}{c}y=47.2481- \\
0.0094 x^{2}+1.3303 x\end{array}$ & $\begin{array}{c}\mathrm{y}=474.5194- \\
0.0006 \mathrm{x}^{3}+ \\
0.1633 \mathrm{x}^{2}- \\
13.8931 \mathrm{x}\end{array}$ \\
\hline
\end{tabular}

Source: calculated by authors according to [34]

Therefore, on the basis of such an S-similar curve, it is necessary to determine the predicted data.

\section{CONCLUSIONS}

Based on a thorough analysis of the legislative acts and practice of using the NBU refinancing instrument, a historical retrospective of Ukraine's use of refinancing operations as a monetary policy instrument was formed and their role as the most influential instrument for regulating the liquidity of the Ukrainian banking system was proved. Based on the obtained results, we can distinguish the following stages of using a refinancing tool: 1) lending to effective innovation and investment projects; 2) stimulating the development of the internal product market; 3 ) regulation of banks' liquidity. This change in the concepts of applying the refinancing instrument has led the focus of the research to identify the relationship between the refinancing mechanism and the level of liquidity of the banking system. As a result, the existence of a close (highest level) inverse relationship between the studied indicators proved that the instrument has a significant impact on banking liquidity. In order to improve the use of the refinancing instrument and increase the efficiency of its application, regression models have been developed, on the basis of which it is recommended to regulate the volume of refinancing in order to change the liquidity level of the banking system.

\section{REFERENCES}

[1] G. Bashnyanin, V. Sidorenko, and M. Lulyk, "Problems of refinancing of banks in the post-crisis period", Scientific bulletin of UNFU of Ukraine, iss. 22.12, pp. 173-177, 2012

[2] M. Boldin, "Experience of the leading countries in supporting banking systems through refinancing (for example, USA, Canada, Japan and PRC)", Bulletin of the Chernivtsi Faculty of the National University “Odessa Law Academy”, iss. 2, pp. 84-94, 2017. 
[3] M. Boldin, "The notion of gaps in legal acts of the NBU in the area of refinancing of Ukrainian banks and ways to fill them", Entrepreneurship, economy and law, no. 5, pp. 166-169, 2017.

[4] G. Bortnikov and H. Panasenko, "Long-term refinancing of banks under crisis", State and regions. Series: Economics and business, no. 6, pp. 73-78, 2015.

[5] M. Chekhovska, "Refinancing of banks in the conditions of transformation of the economic system as a threat to the economic security of Ukraine", Economy and the state, no. 5, pp. 67-70, 2015.

[6] A. Chubenko, M. Loshitsky, D. Pavlov, S. Bychkova, and O. Unin, Terminology dictionary on prevention and counteraction to the legalization (laundering) of proceeds from crime, terrorist financing, financing of the proliferation of weapons of mass destruction and corruption. Kyiv: Vaite, 2018

[7] O. Dzubluk and Yu. Galiceyska, Theoretical and applied aspects of realization by banks of resource policy: monograph. Ternopil: Aston, 2012, $242 \mathrm{p}$.

[8] O. Dzubluk and R. Mikhailuk, Financial stability of banks as the basis for effective functioning of the credit system: monograph. Ternopil: Ternograph, 2009.

[9] S. Egoricheva and S. Prasolova, "Analysis of the role of refinancing in ensuring financial security of Ukrainian banking system", Actual problems of the economy, no. 2, pp. 249-259, 2017.

[10] Yu. Garkusha, "Refinancing of banks: domestic practice", Eastern Europe: economics, business and management, iss. 3(08), pp. 249254, 2017.

[11] Inflation report, $2018 . \quad$ [Online]. Available: https://bank.gov.ua/control/uk/publish/article?art_id=80865512\&cat_ $\mathrm{d}=87678900$. Accessed on: April 11, 2019.

[12] Information day on refinancing of banks. Press release, 2015 [Online]. Available: http://www.bank.gov.ua/doccatalog/document;jsessionid...?id=15638 156. Accessed on: May 20, 2019.

[13] O. Kots, R. Gavdjo, and H. Pistun, "Investigating the impact of refinancing banks on their performance indicators", Global and national problems of the economy, iss. 10, pp. 819-822, 2016.

[14] V. Kovalenko, Strategic management of financial stability of the banking system: methodology and practice: monograph. Sumy: HSEI "UB NBU", 2010.

[15] V. Kovalenko, O. Korenev, K. Cherkashin, and O. Krukhmal, Banking system of Ukraine: monograph. Sumy: HSEI "UB NBU", 2010

[16] O. Kuzmak, "Ensuring the stability of the banking system through refinancing", Scientific notes of Ostroh Academy National University. Economy, iss. 13, pp. 287-294, 2010.

[17] Macroeconomic and Monetary Review, 2017. [Online]. Available: https://bank.gov.ua/control/uk/publish/article?art_id=60027478\&cat_i $\mathrm{d}=62840392$. Accessed on: May 22, 2019.

[18] A. Maksimova, "Refinancing of banks: the mechanism of application, the peculiarities of accounting, analysis, problems and ways of their solution", Science and Economics, iss. 3, pp. 48-59, 2014.

[19] S. Manzhos, "Refinancing as a tool for maintaining the liquidity of Ukrainian banking institutions", Galician economic bulletin, no. 3, pp. 130-138, 2014.

[20] O. Melnichenko, "Refinancing of banks in the conditions of globalization", Scientific bulletin of Kherson state university. Series: Economic Sciences, iss. 7(5), pp. 51-53, 2014.

[21] O. Melnichenko, "Mechanism of refinancing of banks in the contour of globalization processes", Effective economy, no 1, 2015. [Online]. Available: http://nbuv.gov.ua/UJRN/efek_2015_1_30. Accessed on: May 23, 2019.

[22] O. Melnichenko, "The role of refinancing in the emission activities of the National Bank of Ukraine", Bulletin of socio-economic researches, iss. 4, pp. 288-295, 2013.

[23] O. Melnichenko, "Methodical principles of analysis of refinancing of banks of Ukraine", Innovative economy, no. 5, pp. 272-279, 2014.

[24] O. Metlushko, "Modernization of banks' refinancing operations as a factor of stabilization of the financial and credit sphere", Scientific notes of Ostroh Academy National University. Economy, iss. 25, pp. 131-135, 2014
[25] S. Mischenko, "Problems of providing liquidity of banks on the basis of the use of refinancing mechanisms", Finance of Ukraine, no. 7, pp. $75-88,2009$.

[26] V. Mishchenko, et al. Liquidity of the banking system of Ukraine: scientific and analytical materials, iss. 12. Kyiv: National Bank of Ukraine. Center for Scientific Research, 2008.

[27] O. Moskvichova, "Refinancing as one of the forms of state regulation of the credit services market", Scientific notes of Ostroh Academy National University. Economy, iss. 23, pp. 310-314, 2013.

[28] NBU Board Resolution, On approval of the provisional provisions on the procedure for long-term refinancing (maintenance of liquidity) of NBU banks, no. 51, 12.02.2003.

[29] NBU Board Resolution, On approval of the provisional regulation on the procedure for NBU liquidation of Ukrainian banks by refinancing, deposit and other operations, no. 584, 24.12.2003.

[30] NBU Board Resolution, On approval of the provisional regulations on the procedure for lending (refinancing) NBU of long-term lending banks, no. 283, 02.08.2002.

[31] NBU Board Resolution, On approval of the regulation on refinancing and providing NBU loans to Ukrainian banks in order to stimulate lending to the Ukrainian economy for the period of its release to precrisis parameters, no. 47, 04.02.2010.

[32] NBU Board Resolution, On approval of the regulation on the provision of stabilization loans to the banks of Ukraine by the NBU, no. 327, 13.07.2010.

[33] NBU Board Resolution, On approval of the regulations on the use of the NBU standard instruments for regulating the liquidity of the banking system, no. 615, 17.09.2015.

[34] Official site of the NBU, 2019. [Online]. Available: https://bank.gov.ua. Accessed on: April 10, 2019.

[35] Operational data characterizing the liquidity of the banking system and the factors of its change, 2018. [Online]. Available: https://bank.gov.ua/files/Arhiv_liquidity_ukr.xlsx. Accessed on: April $15,2019$.

[36] Resolution of the Cabinet of Ministers of Ukraine and NBU, On the order of refinancing of banks during the financial and economic crisis, no. 44, 29.01.2009.

[37] V. Rudan, "Liquidity of the banking system of Ukraine: current state and strategic management benchmarks", Economic analysis: collection of sciences papers of TNEU, vol. 27, no 4, pp. 170-179, 2017.

[38] G. Saltykova, "Refinancing of banks: world practice and directions of development in Ukraine", Bulletin of Berdyansk University of Management and Business, no. 2(14), pp. 142-145, 2011.

[39] E. Shepel, "Refinancing as one of the forms of liquidity support of Ukrainian banks", Global and national problems of the economy, no. 7, pp. 772-775, 2015

[40] V. Shevchuk, "Trends in the development of the refinancing system of Ukrainian banks", Economist, no. 3, pp. 12-15, 2016.

[41] N. Shulga, "Refinancing of Ukrainian banks", Bulletin of the Kiev national trade and economic university, no. 3, pp. 78-88, 2016.

[42] V. Stelmakh, Monetary policy of the National Bank of Ukraine: current state and prospects for change. Kyiv: Research center of the National Bank of Ukraine, UB NBU, 2009.

[43] Y. Tchaikovsky, "Refinancing of banks as a method of regulation by the NBU of the banking system in the conditions of the financial crisis", Economic analysis, vol. 10(3), pp. 107-111, 2012.

[44] The Law of Ukraine, On the State Budget of Ukraine for 2009, no. 835-VI, 26.12.2008.

[45] The Law of Ukraine, On the National Bank of Ukraine, no. 679-XIV, 20.05.1999.

[46] L. Vdovenko, "Refinancing as a mechanism for maintaining the stability of the banking system", Economy. finances. management: topical issues of science and practice, no. 2, pp. 7-16, 2018.

[47] A. Vozhzhov, Processes of banking resource transformation: monograph. Sevastopol: PH. SevNTU, 2006.

[48] S. Vozhzhov, "The availability of banks to refinance and the possibility of variational regulation of their liquidity", Finance of Ukraine, no. 2, pp. 111-119, 2010 